\title{
Phytoremedial Effect of Pleurotus cornucopiae (Oyster Mushroom) against Sodium Arsenite Induced Toxicity in Charles Foster Rats
}

\author{
Swapnil Suman, Mohammad Ali, Ranjit Kumar, Arun Kumar \\ Mahavir Cancer Institute \& Research Centre, Patna, India \\ Email: arunk31@rediffmail.com
}

Received 11 September 2014; revised 13 October 2014; accepted 28 October 2014

Academic Editor: Feras Darwish El-Hajji, Applied Science Private University, Jordan

Copyright (C) 2014 by authors and Scientific Research Publishing Inc.

This work is licensed under the Creative Commons Attribution International License (CC BY). http://creativecommons.org/licenses/by/4.0/

\section{(c) (i) Open Access}

\begin{abstract}
This study was carried out to investigate the therapeutic role of the ethanolic extract of Pleurotus cornucopiae on sodium arsenite induced nephrotoxicity in rats. Sodium arsenite at the dose of 8 $\mathrm{mg} \cdot \mathrm{kg}^{-1}$ body weight orally caused renal damage in rats as manifested by the significant rise in serum levels of serum urea, uric acid and creatinine level compared with control. Ethanolic extracts of $P$. cornucopiae $\left(400 \mathrm{mg} \cdot \mathrm{kg}^{-1}\right.$ body weight per day) was administered orally for 30 days to sodium arsenite pre-treated rats. The results show significant decrease in the serum urea, uric acid and creatinine levels in comparison to the arsenic treated denotes the nephroprotective effect of $P$. cornucopiae against sodium arsenite induced toxicity. Furthermore, it also possesses antioxidant effect as lipid peroxidation (MDA) levels decreased in $P$. cornucopiae treated group in comparison to arsenic treated group. Thus, the present study reveals that $P$. cornucopiae possesses nephroprotective as well as antioxidant property against arsenic induced toxicity.
\end{abstract}

\section{Keywords}

Pleurotus cornucopiae, Ethanolic Extract, Nephroprotective, Antioxidant

\section{Introduction}

Arsenic is one of the most dangerous occupational and environmental toxins. Both natural and anthropogenic 
sources are responsible for the distribution of many toxicants, mainly heavy metals throughout the environment. Arsenic is abundant in the crust of the earth and is found in all environments. It is found in soil, minerals, surface and groundwater [1]. The arsenic contamination was also observed in three districts Ballia, Varanasi and Gazipur of Uttar Pradesh in the upper and middle Ganga plain, India [2]. Approximately, 20 incidents of groundwater arsenic contamination have been reported from all over the world [3]. Due to groundwater contamination, a large number of populations in Bangladesh are suffering from melanosis, leuco-melanosis, keratosis, hyperkeratosis, dorsum, non-petting oedema, gangrene, skin cancer and skin lesions in sole and palm [4]. Arsenic compounds show toxicity in many organs of body as kidney, liver, lung, gastro intestinal tract and respiratory tract [5]. Kidney shows many renal functions as excretion of nitrogenous waste products, acid-base balance and balance of electrolytes and water. Arsenic trioxide toxicity disturbs these renal functions. Disruption in kidney function has immediate effects on the composition of circulating blood [6]. However, to evaluate the effect of arsenic on kidney functions, it becomes a must to determine the urea, uric acid and creatinine levels in serum [7]. In the current study health promoting effect of Pleurotus cornucopiae, a fungi of basidiomycetes commonly known as "Oyster mushroom" has shown the highly promising effect in combating the arsenic intoxication in Charles foster rats. For the last few decades, extensive work has been done to establish the biological activities and Pharmacological actions of Pleurotus cornucopiae and its extract, such as anti-inflammatory, antioxidant, anticarcinogenic, anticoagulant, antifertility, antidiabetic, antibacterial and antifungal activities etc. Hepatoprotective effect of Pleurotus cornucopiae against arsenic induced toxicity in rats has also been observed in recent studies [8]. With such a background, our initial aim was to find out suitable herb to modulate arsenic poisoning, which should be 1) easy to administer, 2) effective in low dose, 3) inexpensive, and 4) relatively safe.

\section{Materials and Methods}

\subsection{Animals}

Thirty Charles Foster rats, weighing $160 \mathrm{~g}$ to $180 \mathrm{~g}$ of 8 weeks old in the ratio of 1:2 male and female in each group were obtained from animal house of Mahavir Cancer Institute and Research Centre, Patna, India (CPCSEA Regd-No. 1129/bc/07/CPCSEA). The research work was approved by the IAEC (Institutional Animal Ethics Committee) with IAEC No. IAEC/2012/12/04. Food and water to rats were provided ad libitum.

\subsection{Fungal Extract}

Pleurotus cornucopiae, also known as branched oyster mushroom, is an edible mushroom used to flavour many types of foods. These mushrooms receive their common name from the white, round caps of their fruiting bodies, which resemble oysters. In the present study, fresh fruiting body of Pleurotus cornucopiae were collected from the Rajendra Agriculture University (RAU), Pusa, Samastipur, Bihar, India. The identity of the mushroom was confirmed by Dr. Ramakant Pandey (Botanist), Department of Biochemistry, Patna University, Patna, Bihar, India. The mushroom was shade dried and was grinded to fine powder. The powder was then soaked in $70 \%$ ethanol for 48 hours and finally extracted with absolute ethanol using soxhlet apparatus for 6 - 8 hours and the residue was concentrated and dried at $37^{\circ} \mathrm{C}$. The dose was finally made to $400 \mathrm{mg} \cdot \mathrm{kg}^{-1}$ body weight for oral administration.

\subsection{Chemical}

"Sodium Arsenite AR"-Lobachemie, Mumbai, India (CAS Number: 7784-46-50) was utilised in the present study to induce arsenic caused nephrotoxicity.

\subsection{Experimental Design}

The animals were divided into five sets and each set comprised 6 rats. The Group I were normal control rats, the Group II were arsenic treated rats for 45 days, the Group III was arsenic pre-treated (45 days) rats to which further no treatment was given and left alone for 30 days, the Group IV was P. cornucopiae ethanolic extract 400 $\mathrm{mg} \cdot \mathrm{kg}^{-1}$ body weight treated rats for 30 days on sodium arsenite $8 \mathrm{mg} \cdot \mathrm{kg}^{-1}$ body weight pre-treated rats and Group V was $P$. cornucopiae $400 \mathrm{mg} \cdot \mathrm{kg}^{-1}$ body weight + arsenic $8 \mathrm{mg} \cdot \mathrm{kg}^{-1}$ body weight treated rats for 30 days. After the completion of the experimental period, the entire animals were anaesthetized by diethyl ether for 5 minutes and sacrificed. 


\subsection{Renal Function Assay}

After the entire treatment protocol the experimental animals were sacrificed. Blood sample was collected by orbital sinus puncture method [9] and their serum was extracted. The Kidney Function Test (KFT) Urea [10], Uric acid [11] and Creatinine [12] [13] were performed from serum through their respective methods.

\subsection{Lipid Peroxidation Assay}

Serum lipid peroxidation (LPO) was also assayed in all the respective groups [14]. Thiobarbituric acid reactive substances (TBARS), as a marker for LPO, were determined by the double heating method. The theory of the method was a spectrophotometric measurement of the colour produced during the reaction to Thiobarbituric acid (TBA) with malondialdehyde (MDA). For this intention, $2.5 \mathrm{ml}$ of $100 \mathrm{~g} / \mathrm{l}$ tri-chloroacetic acid (TCA) solution was added to $0.5 \mathrm{ml}$ serum in a centrifuge tube and incubated for $15 \mathrm{~min}$ at $90^{\circ} \mathrm{C}$. After cooling at room temperature (RT), the mixture was centrifuged at $3000 \mathrm{~g}$ for $10 \mathrm{~min}$, and $2 \mathrm{ml}$ of the supernatant was added to $1 \mathrm{ml}$ of 6 . $7 \mathrm{~g} / \mathrm{l} \mathrm{TBA}$ solution in a test tube and again incubated for $15 \mathrm{~min}$ at $90^{\circ} \mathrm{C}$. The solution was then cooled at RT and its absorbance was measured using Thermo Scientific UV-10 (UV-Vis) spectrophotometer (USA) at 532 nm.

\subsection{Statistical Analysis}

Results are presented as mean \pm S.D and total variation present in a set of data was analyzed through one-way analysis of variance (ANOVA). Difference among means has been analyzed by applying Dunnet's test at $99.9 \%$ ( $\mathrm{p} \leq 0.001$ ) confidence level. Calculations were performed with the Graph Pad Prism Program (Graph Pad Software, Inc., San Diego, USA).

\section{Results}

\subsection{Morbidity and Mortality}

The rats after arsenic exposure ( $8 \mathrm{mg} \cdot \mathrm{kg}^{-1}$ body weight) for 45 days had shown symptoms of toxicity such as nose bleeding, nausea, lack of body co-ordination (11 percent of rats showed paralysis like symptoms), blackening of tongue and foot and general body weakness.

\subsection{Biochemical Changes}

The Urea, Uric acid, Creatinine and lipid peroxidation activity showed significant increase $(\mathrm{p}<0.05)$ in arsenic treated group in comparison to control rat group. But, these values are significantly lowered $(\mathrm{p}<0.05)$ in $P$. cornucopiae treated group. Arsenic intoxicated group showed a significant increase in serum uric acid, urea and creatinine content as compared to control after acute treatments ( $\mathrm{p}<0.05)$. When Group I: control rats, Group II: arsenic intoxicated rats for 45 days, Group III: 45 days arsenic intoxicated rats left for 30 days without any herbal treatment, Group IV: 45 days arsenic intoxicated rats treated with P. cornucopiae and Group V: P. cornucopiae + arsenic treated rats for 30days were compared, a significant $(\mathrm{p}<0.05)$ difference was obtained (Figures 1-4).

\section{Discussion}

Among possible target organs of heavy metals like arsenic, the kidney and central nervous system appear to be the most sensitive ones. Having been absorbed from the alimentary tract, most of the metals form durable combination with the protein thionein, forming metallothionein, which plays an important role in further metabolism of these metals [15] [16]. The kidney and liver are considered to be the most vulnerable organs for metals, because these organs contain most of the metallothionein binding toxic metals [17] [18]. After then arsenic reaches the liver, where its biotransformation takes place and is finally sent to kidney through blood to be excreted out of the body. In kidney, arsenic exerts its deleterious toxic effects through several mechanisms, the most significant of which is the reversible combination with suflydryl group of proteins present in glomerular filtration membrane [19]. It causes oxidative damage by producing reactive oxygen species [5] [20] which damage proteins. Due to lipophilic in nature, arsenic also attaches to lipid, increases the lipid peroxidation [21] resulting in 


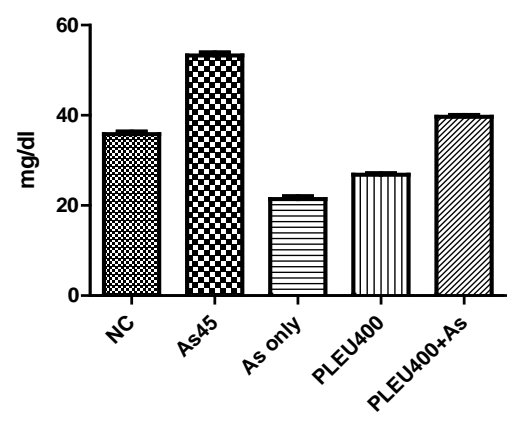

Figure 1. Comparison of serum Urea levels among normal control, arsenic treated for 45 days, arsenic only, P. cornucopiae $400 \mathrm{mg} \cdot \mathrm{kg}^{-1}$ body weight treated and $P$. cornucopiae + arsenic treated rats.

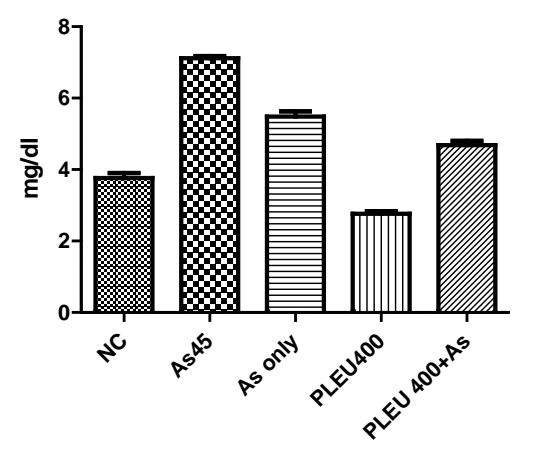

Figure 2. Comparison of serum uric acid levels among normal control, arsenic treated for 45 days, arsenic only, P. cornucopiae $400 \mathrm{mg} \cdot \mathrm{kg}^{-1}$ body weight treated and P.cornucopiae + arsenic treated rats.

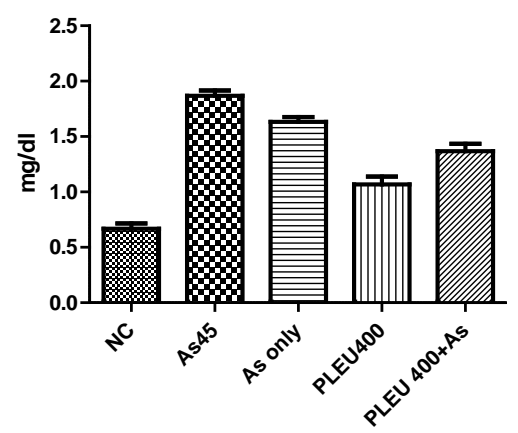

Figure 3. Comparison of serum creatinine levels among normal control, arsenic treated for 45 days, arsenic only, P. cornucopiae $400 \mathrm{mg} \cdot \mathrm{kg}^{-1}$ body weight treated and $P$. cornucopiae + arsenic treated rats.

deposition of lipid droplets in the slit pores of glomerular filtration membrane. Both the reasons discussed above cause decreased glomerular filtration rate (GFR), thereby causing accumulation of nitrogenous waste product in blood. In the present study also, there was immense increase in the levels of lipid peroxidation (MDA) levels denotes the similar pattern of study but there was declination in the levels of the same by the ameliorative effect of ethanolic extract of $P$. cornucopiae denotes the antioxidant activity.

The serum uric acid concentration is determined largely by the efficiency of renal clearance and rate of purine metabolism [22]-[25]. Uric acid has important antioxidant property in vivo [26] and in vitro [27]. Uric acid is the final product of purine metabolism. Moreover, formed from guanine and hypoxanthine via xanthinein reactions 


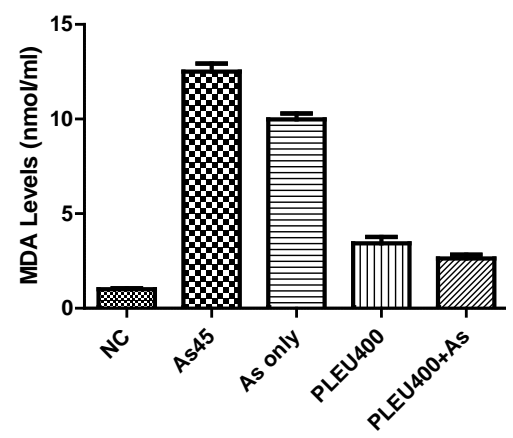

Figure 4. Comparison of Lipid peroxidation levels among normal control, arsenic treated for 45 days, Arsenic only, P. cornucopiae $400 \mathrm{mg} \cdot \mathrm{kg}^{-1}$ body weight treated and P. cornucopiae + Arsenic treated rats.

catalysed by guanase and xanthine oxidase of liver, small intestine and kidney. Arsenic intoxication changes the activity of guanase and xanthine oxidase which results into the increased serum level of uric acid. However, renal clearance of uric acid decreases with simultaneous increase in serum uric acid. But, ethanolic extract of $P$. cornucopiae might be reducing the lipid Peroxidation due to which the serum level of uric acid becomes normalized and due to its antioxidant property it inhibited generation of reactive oxygen species.

Urea is the end product of protein metabolism, gets increased and serum level of urea increases [22] [28] revealed that production of oxygen free radicals by arsenic induces tubular necrosis which inturn increases tubular permeability, resulting in diffusion and back leak of the filtrate across the tubular basement membrane back into the interstitium and circulation, leading to an apparent decrease in GFR. Under these circumstances, back leak of filtrate results in decreased excretion and increased retention of nitrogenous waste i.e. urea in serum [29] [30]. But, after administration of ethanolic extract of $P$. cornucopiae, arsenic probably attaches to the thiol group of $P$. cornucopiae protein instead of body protein, as a result of which protein metabolism becomes normal leading to increased serum level of urea to be normal.

The increased level of serum creatinine after arsenic intoxication is due to enhanced formation of metabolic waste product of muscle metabolism. Further, creatinine is anhydride of creatinine. Muscle contains phosphocreatinine which undergoes spontaneous cyclization with loss of inorganic phosphorous to form creatinine. Due to affinity for thiol group of various proteins found in the cell membrane of muscles, arsenic damages the cells due to which the enzyme CPK (Creatine phosphokinase) gets released from the cells which is responsible for the conversion of phosphocreatinine in to creatinine, thus increases the level of creatinine. Probably, in presence of ethanolic extract of $P$. cornucopiae, arsenic does not attach to the proteins of muscle cells but to the P. cornucopiae protein, thus the serum levels of creatinine gets normalised. Among all the treatment groups, $P$. cornucopiae alone administered to arsenic pre-treated groups shows better amelioration rather than other groups. Thus, from the entire study it reveals that $P$. cornucopiae ethanolic extract alone plays the vital role in ameliorating the arsenic induced nephrotoxicity.

\section{Conclusion}

The study thus shows that ethanolic extract of $P$. cornucopiae possesses antidote and nephroprotective activity against arsenic intoxication. It also finds application as a novel drug in the near future to be used against arsenic intoxication.

\section{Declaration of Interest}

The authors extend their appreciation to the Department of Science \& Technology, (SSTP Division) Ministry of Science \& Technology, Government of India, New Delhi for the financial assistance of this work and to the institute for the entire infrastructural facilities.

\section{References}

[1] Antman, K.H. (2001) Introduction: The History of Arsenic Trioxide in Cancer Therapy. The Oncologist, 6, 1-2. 
http://dx.doi.org/10.1634/theoncologist.6-suppl_2-1

[2] Ahamed, S., Sengupta, M.K., Mukherjee, A., Hossain, M.A., Das, B., Nayak, B., Pal, A., Mukherjee, S.C., Pati, S., Dutta, R.N., Chatterjee, G., Mukherjee, A., Srivastava, R. and Chakraborti, D. (2006) Arsenic Groundwater Contamination and Its Health Effects in the State of Uttar Pradesh (UP) in Upper and Middle Ganga Plain, India: A Severe Danger. Science of the Total Environment, 370, 310-322. http://dx.doi.org/10.1016/j.scitotenv.2006.06.015

[3] Mukherjee, A., Sengupta, M.K. and Hossain, M.A. (2006) Arsenic Contamination in Groundwater: A Global Perspective with Emphasis on the Asian Scenario. Journal of Health, Population, and Nutrition, 24, 142-163.

[4] Karim, M. (2000) Arsenic in Groundwater and Health Problems in Bangladesh. Water Research, 34, 304-310. http://dx.doi.org/10.1016/S0043-1354(99)00128-1

[5] Vahter, M.E. (2007) Interactions between Arsenic Induced Toxicity and Nutrition in Early Life. Journal of Nutrition, 137, 2798-2804.

[6] Martini, F. (1989) Fundamentals of Anatomy and Physiology. Prentice Hall, Englewood Cliffs, 944.

[7] Saxena, P.N., Mahour, K. and Kumar, A. (2006) Protective Effect of Panax ginseng Extract on Renal Functions Altered by Mercuric Chloride in Albino Rats. Journal of Ginseng Research, 30, 100-105. http://dx.doi.org/10.5142/JGR.2006.30.3.100

[8] Kumar, A., Suman, S., Kumar, R., Singh, J.K. and Ali, M. (2014) Hepatoprotective Effect of Edible Oyster Mushroom Pleurotus cornucopiae against Sodium Arsenite Induced Hepatotoxicity in Rats. International Journal of Phytomedicine, 6, 275-279.

[9] Van Herck, H., Baumans, V., Brandt, C.J., Hesp, A.P., Sturkenboom, J.H., Van Lith, H.A., Van Tintelen, G. and Beynen, A.C. (1998) Orbital Sinus Blood Sampling in Cats as Performed by Different Animal Technician: The Influence of Technique and Expertise. Laboratory Animals, 32, 377-386. http://dx.doi.org/10.1258/002367798780599794

[10] Berthelot, M.P.E. (1859) Berthelot's Reaction Mechanism. Report de Chimie Applique, 2884.

[11] Fawcett, J.K. and Scott, J.E. (1960) A Rapid and Precise Method for the Determination of Urea. Journal of Clinical Pathology, 13, 156-159. http://dx.doi.org/10.1136/jcp.13.2.156

[12] Bonsnes, R.W. and Taussky, H.H. (1945) On Colorimetric Determination of Creatinine by the Jaffe Reaction. The Journal of Biological Chemistry, 158, 581-591.

[13] Toro, G. and Ackermann, P.G. (1975) Practical Clinical Chemistry. Little Brown and Co., Boston, 154.

[14] Draper, H.H. and Hadley, M. (1990) Malondialdehyde Determination as Index of Lipid Peroxidation. Methods in Enzymology, 186, 421-431. http://dx.doi.org/10.1016/0076-6879(90)86135-I

[15] Maitani, T., Saito, N., Abe, M., Uchiyama, S. and Saito, Y. (1987). Chemical Form Dependent Induction of Hepatic Zinc-Thionein by Arsenic Administration and Effect of Co-Administered Selenium in Mice. Toxicology Letters, 39, 63-70. http://dx.doi.org/10.1016/0378-4274(87)90257-8

[16] Peraza, M.A., Fierro, F.A., Barber, D.S., Casarez, E. and Rael, L.T. (1998) Effects of Micronutrients on Metal Toxicity. Environmental Health Perspectives, 106, 203-216.

[17] Choudhary, H., Harvey, T., Thayer, W.C., Lockwood, T.F., Stitelor, W.M., Goodrum, P.E., Hasset, J.M. and Diamond, G.L. (2001) Urinary Cadmium Elimination as a Biomarker of Exposure for Evaluating a Cadmium Dietary ExposureBiokinetics Model. Journal of Toxicology and Environmental Health, Part A, 63, 221-250.

[18] Hollis, L., Hogstrand, C. and Wood, C.M. (2001) Tissue-Specific Cadmium Accumulation, Metallothionein Induction, and Tissue Zinc and Copper Levels during Chronic Sublethal Cadmium Exposure in Juvenile Rainbow Trout. Archives of Environmental Contamination and Toxicology, 41, 468-474. http://dx.doi.org/10.1007/s002440010273

[19] Yoon, S., Han, S.S. and Rana, S.V.S. (2008) Molecular Markers of Heavy Metal Toxicity-A New Paradigm for Health Risk Assessment. Journal of Environmental Biology, 29, 1-14.

[20] Flora, S.J.S., Bhadauria, S., Kanan, G.M. and Singh, N. (2007) Arsenic Induced Oxidative Stress and the Role of Antioxidant Supplementation during Chelation: A Review. Journal of Environmental Biology, 28, 333-347.

[21] Farombi, E.O., Adelow, O.A. and Ajimoko, Y.R. (2007) Biomarkers of Oxidative Stress and Heavy Metal Levels as Indicators of Environmental Pollution in African Cat Fish (Clarias gariepinus) from Nigeria Ogunriver. International Journal of Environmental Research and Public Health, 4, 158-165. http://dx.doi.org/10.3390/ijerph2007040011

[22] Anetor, J.I. (2002) Serum Uric Acid and Standardized Urinary Protein: Reliable Bioindicators of Lead Nephropathy in Nigerian Lead Workers. African Journal of Biomedical Research, 5, 19-24.

[23] Chandra Sekhar, K., Chary, N.S., Kamala, C.T., Venkatesware Rao, J., Balaram, V. and Anjaneya, Y. (2003) Risk Assessment and Pathway Study of Arsenic in Industrially Contaminated Sites of Hyderabad: A Case Study. Environment International, 29, 601-611. http://dx.doi.org/10.1016/S0160-4120(03)00017-5

[24] Dioka, C.E., Orisakwe, O.E., Adeniyi, F.A. and Meludu, S.C. (2004) Liver and Renal Function Tests in Artisans Occu- 
pationally Exposed to Lead in Mechanic Village in Nnewi, Nigeria. International Journal of Environmental Research and Public Health, 1, 21-25. http://dx.doi.org/10.3390/ijerph2004010021

[25] Kalia, K. and Flora, S.J.S. (2005) Strategies for Safe and Effective Therapeutic Measures for Chronic Arsenic and Lead Poisoning. Journal of Occupational Health, 47, 11-21. http://dx.doi.org/10.1539/joh.47.1

[26] Hink, H.U., Santanam, N. and Dikalov, S. (2002) Peroxidase Properties of Extracellular Superoxide Dismutase: Role of Uric Acid in Modulating in Vivo Activity. Arteriosclerosis, Thrombosis, and Vascular Biology, 22, 1402-1408. http://dx.doi.org/10.1161/01.ATV.0000027524.86752.02

[27] Ames, B.N., Cathcart, R., Schwiers, E. and Hochst, P. (1981) Uric Acid Provides an Antioxidant Defence against and Radical Caused Aging and Cancer: A Hypothesis. Proceedings of the National Academy of Sciences of the United States of America, 78, 6858-6862. http://dx.doi.org/10.1073/pnas.78.11.6858

[28] Aphosian, H.V. (1989) Biochemical Toxicology of Arsenic. In: Hodgson, E., Bend, J.R. and Philpot, R.M., Eds., Reviews in Biochemical Toxicology, Vol. 10, Elsevier Science Publishing Co., New York, 265-299.

[29] Klassen, C.D. (1996) Heavy Metals and Heavy Metal Antagonists. In: Hardman, J.G., Gilman, A.G. and Limbird, L.E., Eds., Goodman and Gilman's the Pharmacological Basis of Therapeutics, McGraw-Hill, New York, 1649-1672.

[30] Verbeke, M., Van De Voorde, J. and Lameire, N. (1996) Prevention of Experimental Acute Tubular Necrosis: Current Clinical Applications and Perspectives. Advances in Nephrology from the Necker Hospital, 25, 177-216. 
Scientific Research Publishing (SCIRP) is one of the largest Open Access journal publishers. It is currently publishing more than 200 open access, online, peer-reviewed journals covering a wide range of academic disciplines. SCIRP serves the worldwide academic communities and contributes to the progress and application of science with its publication.

Other selected journals from SCIRP are listed as below. Submit your manuscript to us via either submit@scirp.org or Online Submission Portal.
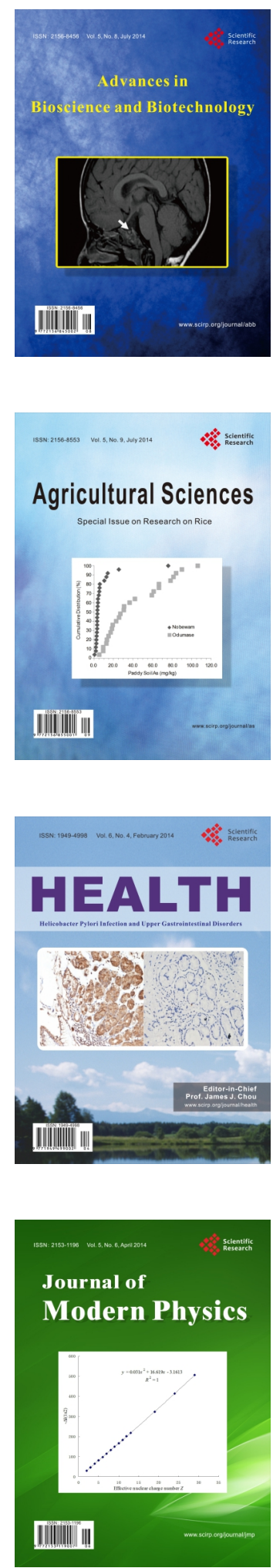
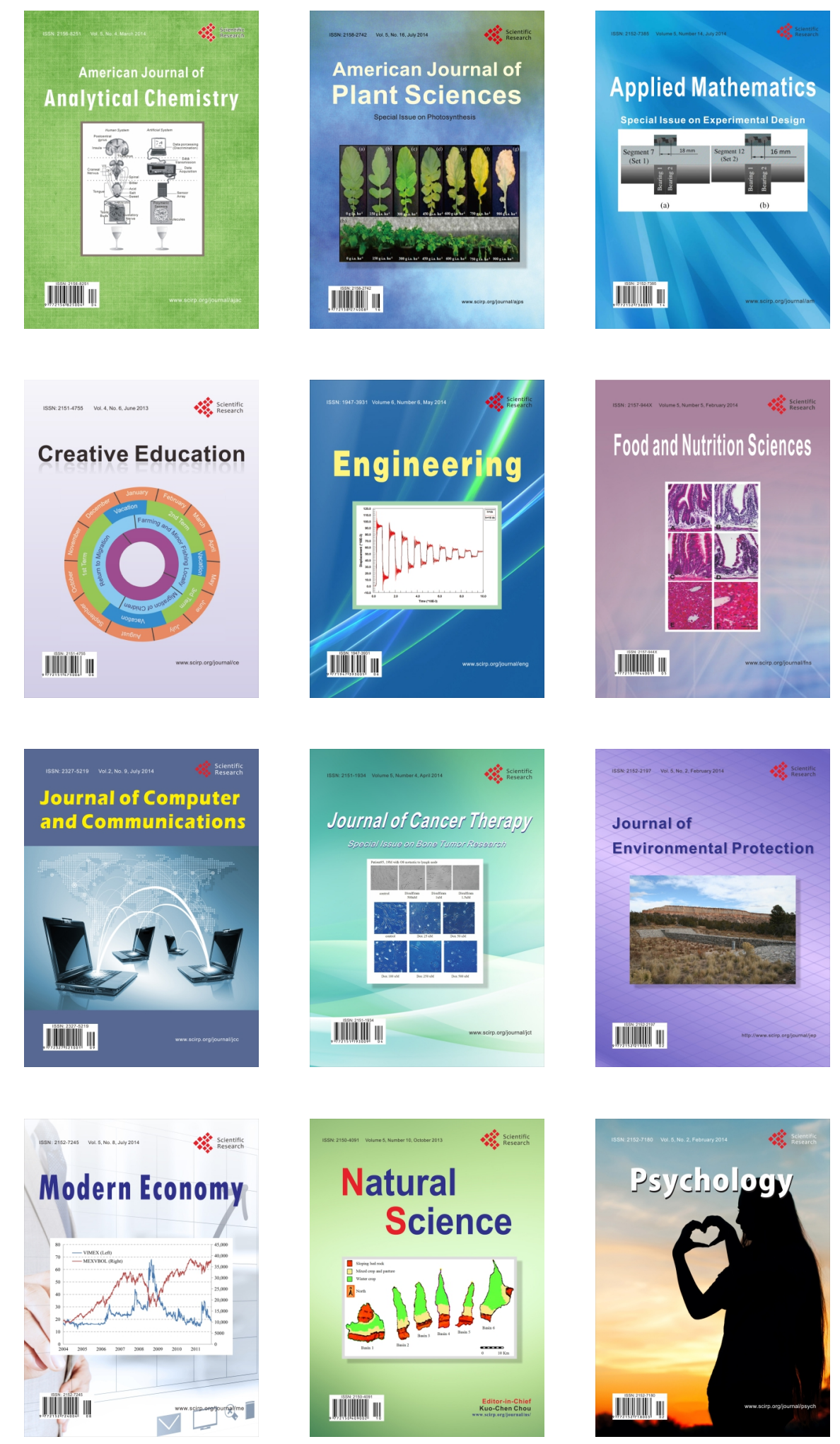